\title{
Kerkbegrip en kerkorde
}

S J Botha

Universiteit van Pretoria

\begin{abstract}
Church and church order

This paper discusses the connection and relationship between church and church order within the context of the presbyterial-synodal system of church polity with a view to the rewriting of the church order of the Nederduitsch Hervormde Kerk van Afrika. This presbyterial-synodal system was build on the basic principles of Calvin's ecclesiology and corresponding church polity. These basic principles found its way to the confessions of the Nederduitsch Hervormde Kerk.
\end{abstract}

\section{INLEIDING}

Die ter sake onderwerp is die verband en verhouding tussen kerkbegrip en kerkorde binne die konteks van die presbiteriaal-sinodale kerkregeringstelsel met die oog op die herskrywing van die Kerkwet (Kerkorde) van die Nederduitsch Hervormde Kerk.

Die Algemene Kerkvergadering van die Nederduitsch Hervormde Kerk het in 1989 besluit dat die Kerkwet hersien, herformuleer, herrangskik en aangepas moes word (Nederduitsch Hervormde Kerk 1989 = NHKA 1989:44, 247). Wanneer dan na hierdie vierledige opdrag gekyk word, is dit wel duidelik dat die kerk heelwat gebreke in sy Kerkwet waargeneem het wat reggestel moes word. Die komitee wat aangewys is om die opdrag uit te voer, het na aanvanklike worsteling daarmee geoordeel dat uitvoering van hierdie opdragte nog nie sake sal regstel wat die kerk beoog het nie, en het in 1992 aan die Algemene Kerkvergadering gerapporteer: ' $\ldots$ dit sal wys wees om nie net die bepaalde Kerkwet te hersien en aan te pas nie, maar om 'n totaal nuwe Kerkwet daar te stel' (NHKA 1992:259).

Die besluit van die Algemene Kerkvergadering om hierdie aanbeveling te aanvaar, verteenwoordig 'n drastiese en radikale gebeurtenis. Dit gebeur nie aldag dat 'n kerk besluit op ' $n$ totaal nuwe kerkwet of kerkorde nie (Botha 1993:14).

Dit is seker voor die hand liggend, logies en ook noodsaaklik dat die onderneming van so 'n omvangryke groot projek, die aangeleentheid van kerkbegrip en kerkorde in hulle onderlinge verband en verhouding ook onder die soeklig geplaas sal word. Trouens dit is ondenkbaar dat enige kerkorde opgestel kan word wat nie op 'n kerk- 
begrip gebaseer is nie (Van Wyk 1989:27). Terselfdertyd is 'n kerkbegrip wat nie uitmond in 'n kerkorde' nie, in werklikheid niks meer as slegs 'n vae, onsekere en swewende idee nie. Van Ruler se uitspraak: 'Eerst wanneer men iets van de kerk ook kerkrechtelijk kan uitdrukken, weet men echt, waar men het over heeft' is hier ter sake (Van Ruler 1969:314).

Om oor kerkbegrip en dan spesifiek in relasie tot kerkorde te handel is ook nie so 'n eenvoudige saak nie. Dit is nie sonder rede nie dat Noordmans gesê het:

Wij merken wel dat het niet zo eenvoudig is om - wat men soms zo noemt - een kerkbegrip te hebben. De kerk verzet er zich als het ware tegen om begrepen te worden.

(Noordmans, in Van Wyk 1989:26)

Terwyl die kerk in die eerste plek 'n geloofswerklikheid is, is daar tog ook sprake van 'n empiriese kant. Om hierdie 'dubbelheid' uit te druk word ook gepraat van 'n organisme met 'n institutêre sy (Langman 1950:182) of dalk van 'n geestelike en organisatoriese, strukturele of kerkordelike grootheid (Van Niftrik 1953:229-239). Van Ruler betoog dat die kerk ' $n$ veelomvattende 'pneumatische werkelijkheid' is, maar dan is die institutêre net so pneumaties as al die ander elemente en dimensies (Van Ruler 1969:309).

Die presbiteriaal-sinodale konteks waarbinne die kerkbegrip en kerkorde geplaas moet word, beteken dat die hooflyne van dié bepaalde kerkbegrip en die daarop gefundeerde kerkregeringstelsel, kortliks aan die orde gestel sal moet word. Kerkbegrip en kerkorde word dus hier beperk tot die presbiteriaal-sinodale konteks en nie in algemene sin aan die orde gestel nie.

\section{JOHANNES CALVYN}

Daar bestaan geen twyfel daaroor dat Calvyn die vader van die presbiteriaal-sinodale vorm van kerkregering is nie (Van Wyk 1989:15; Smit 1985:97). Hy het juis hierdie vorm van kerkregering ontwikkel om sy bepaalde kerkbegrip te kon dra (Pont 1981:34). Tog is dit nie so dat Calvyn se kerkbegrip deur 'n strak, juridies uitgewerkte kerkstruktuur bepaal word nie (Smit 1985:81). Hier blyk alreeds by implikasie wat die aard van die verband en verhouding van kerkbegrip en kerkorde in hierdie konteks is: die kerkbegrip bepaal die kerkorde, of soos Haitjema (1951:8) dit stel, dat die kerkbegrip 'de lichtende ondergrond van alle kerkrechtelijke regelingen blijven moet'.

Volgens Milner (1970:7), wat Calvyn se ekklesiologie in al sy geskrifte sorgvuldig nagevors het, gebruik Calvyn feitlik deurgaans metafore wat die kerk met 'n organisme vergelyk, dit wil sê met 'n geskape, lewende en histories ontplooiende realiteit. 
Hieraan verbind Calvyn dan verder die begrip orde. Milner stel (1970:9): 'implicit in the notion of organism, therefore, is the conception of order'. Volgens Calvyn het God met die skepping in alle opsigte orde daargestel. Die sondeval, wat niks anders as hoogmoed, ongehoorsaamheid en veral ontrou was nie, het die totale orde verwring en die mens van God vervreem (Milner 1970:37). Dan skep God die kerk om weer orde in die skepping te herstel. Daarom kan Milner dan stel (1970:47): 'The church is not so much an institution in history in which the restoration of order has been accomplished, as it is itself the history of that restoration'.

Voorts toon Milner aan dat die kerk wat 'n lewende organisme is, gebou en gevestig is in die verbond (Milner 1970:46-58). Saam met Van Wyk sou op grond van Milner se navorsing gekonkludeer kan word dat Calvyn se kerkbegrip in die genadeverbond berus en daarom ook as volkome Skriftuurlik beskryf kan word (Van Wyk 1989: 19). Volgens Milner het die kerk die verbond as geboortereg ontvang toe dit die eerste lig gesien het in die uitverkiesing en roeping van Abraham (Milner 1970:52).

Om Calvyn se beskouing van die verbond 'n bietjie verder te voer: Die oomblik toe Jesus Christus uit die dood opgestaan het, is die verbond oopgemaak om ook diegene te omvat wat nie die natuurlike afstammelinge van Abraham was nie. Hy ken net een verbond wat in en deur Christus vernuwe is. Hy onderskei wel 'n ou en nuwe bedeling met Christus in die middelpunt. Met die oopmaak van die verbond en die opname van die heidene (of soos daarna in Rom 11:17 verwys word as die ent van die takke van die wilde olyf op die stam van die mak olyf), is daar wel 'n nuwe moment in die lewe van die verbondsgemeenskap, die kerk, ingedra (Pont 1986:538).

Waar dit vroeër net Israel was wat aan die electio generalis deel gehad het, kry alle volke nou daaraan deel omdat die evangelie nou aan alle volke verkondig word op so 'n wyse dat die verbond aan elkeen in bewaring gegee word. In elke volk word die kerk dus volkskerk. Maar nie almal wat deel het aan die electio generalis, die sigbare verbond, het ook deel aan die besondere uitverkiesing wat net deur God self, die Heilige Gees, geskenk word nie. Dit gaan dan om 'n sigbare verbondsgemeenskap of kerk van gedoopte en belydende lidmate, wat egter 'n corpus permixtum is en andersyds om die onsigbare kerk wat uit die uitverkorenes wat alleen aan God bekend is, bestaan (Pont 1986:539).

Om te kan weet of die sigbare kerk wel as ware kerk erken kan word praat Calvyn van twee notae ecclesiae naamlik die regte prediking en aanhoor van die evangelie en die regte bediening en ontvang van die sakramente. 
By die nagaan van sy opvatting oor die twee merktekens van die kerk, stel Milner dat Calvyn se denke ongetwyfeld in gedagte het dat wanneer die prediking van die Woord en die bediening van die sakramente, wat beide deur God ingestel is, begelei word deur die doeltreffende werking van die Heilige Gees, dan konstitueer hulle die orde wat die realiteit van die kerk aantoon. Milner (1970:132) stel dit so:

With respect to both marks, the order is two fold: there is, on the one hand, an order of true preaching of the word of 'God and right administration of the sacraments, and, on the other hand, the order which appears when the word is truely heard and the sacraments faithfully received. It is in their coalescence of course, that the existence of the church is 'marked'.

Die dinamiese faktor wat korrelasie skep tussen prediking en hoor, bediening en ontvangs is die Heilige Gees. Natuurlik sou die Heilige Gees ook los van prediking en sakrament op 'n 'buitengewone' wyse geloof kon wek. Die 'normale' is egter deur prediking en bediening van die sakramente. Prediking en sakramente is nie maar net tekens van 'n werklikheid wat onafhanklik en los van hulle bestaan nie: vanuit menslike oogpunt is hulle wesenlik van daardie werklikheid. Die kerk moet nie verstaan word as 'n wetlike omskrewe instituut waar die Woord reg verkondig en die sakramente korrek bedien word, of as iets misties waar dit net gaan om die teenwoordigheid van Christus sonder ' $n$ objektiewe orde nie. 'Rather, the church must be defined dialectically as union with Christ in, through, and together with the means by which the Spirit brings us to him' (Milner 1970:133). Tereg word Calvyn en saam met hom ook Bucer, teoloog van die kerk en teoloog van die Heilige Gees genoem (Van't Spijker 1994:33).

Calvyn het nie die notae as abstrakte maatstawwe gesien nie, maar as werklikhede wat die kerk sigbaar laat word die oomblik as hulle na vore kom. Dan hou dit ook in dat God self teenwoordig is. Waar reg gepreek en die sakramente reg bedien word, daar is God wel teenwoordig (Pont 1986:540). God is dus nie vanselfsprekend in die sigbare kerk teenwoordig nie, want Hy kan op geen wyse in die sigbare kerk vasgevang word nie. Daarom word die sigbare kerk telkens ware kerk as reg gepreek en die sakramente korrek bedien word. Dit is immers God self wat aan die werk is in die regte prediking en die korrekte sakramentsbediening hoewel $\mathrm{Hy}$ van 'n geroepe menslike dienaar gebruik maak.

Calvyn se beskouing oor en beklemtoning van die prediking en sakramente as die konstituerende elemente vir die kerk, maak dit daarom ook logies en vanselfsprekend dat hy aan die amp en erediens of godsdiensoefening, 'n besondere plek in sy kerk- 
begrip sal toeken. In hierdie denke vorm die erediens die hoogtepunt en hartklop van die totale lewe van die kerk. Dit is waar die Heilige Gees deur die instrumente van prediking en sakramentsbediening die gemeente, die gelowiges, die volk van God, aan Hom vasmaak, by Hom hou en hulle oefen in die geloof. Daarom kan Calvyn in sy kommentaar op Hosea 9:5 verklaar:

It would be better for us to be deprived of meat and drink, and to go naked, and to perish at last through want, than that the exercises of religion by which the Lord holds us, as it were, in his own bosom, should it be taken away from us.

(Calvyn, in Milner 1970:157)

Die erediens dui die sin en doel van die kerk ook duidelik aan: die dien van God tot eer van God.

Die prediking van die Woord en die bediening van die sakramente vooronderstel die ampte, nie omdat die ampte op enige wyse bepalend is vir prediking en sakrament nie, maar wel omdat dit God se wil is om van die diens van mense gebruik te maak (Milner 1970:134). Volgens hierdie beskouing is dit waar die wortel van die amp lê. Die amp is instrument in die hand van God (Pont 1981:11).

Wanneer oor die ampte gehandel word, is Calvyn baie duidelik dat dit dan gaan 'oor die orde waarmee dit die Here se wil was dat sy kerk regeer moet word' (Calvyn 1991:1317). Die regering van die kerk is nie maar ' $n$ uitvindsel van mense nie, maar is afhanklik van die opdrag van God. In sy kommentaar op die Hebreërbrief 5:4 stel Calvyn dat '... no government is to be set up in the Church by the will of men, but we are to wait for the command of God ...' (Calvyn 1949:116). Hier moet Calvyn se gedagte dat die kerk ook koninkryk van Christus genoem kan word, ter sprake gebring word.

Gegrond in die uitgangspunt dat Jesus Christus die ampte van Koning en Priester beklee, gebruik Calvyn dikwels twee metafore, naamlik die kerk as koninkryk van Christus en as liggaam van Christus (Milner 1970:164). Hierdie twee ampte van Christus - sy versoenende sterwe (as Priester) en sy hemelse regering (as Koning) word in die kerk gerealiseer deur die werking van die Heilige Gees. Milner verklaar:

The kingly and priestly offices of Christ correspond then to the sanctification (regeneration) and justification (reconciliation, forgiveness) of man; for Calvin, one might say, Christ died for our justification and rose for our sanctification.

(Milner 1970:165)

Dit alles word egter eers werksaam in ons deur die werking van die Heilige Gees. 
By die gedagte van die kerk as koninkryk van Christus en as liggaam van Christus kom die orde, tug of dissipline vir Calvyn ter sprake. Dit impliseer tog duidelik die regering van Christus as Heer en Hoof van die kerk. Dit is al meermale aangetoon dat die grondbeginsel van Calvyn se kerkbegrip die Hoofskap van Jesus Christus is (Smit 1985:81). In die kerkorde gaan dit dan juis 'om die vraag hoe die Hoof of Koningskap van Jesus Christus in en van sy kerk, gestalte moet kry' (Pont 1981:11).

Dit is egter belangrik om daarop te let dat Calvyn aan die een kant baie duidelik laat blyk 'dat die kerklike orde 'n sekondêre saak is wat nie die wese van die kerk raak nie' (Pont 1986:540), maar terselfdertyd die saak van die orde so beklemtoon dat sy opvolgers en geesgenote - 'mischien zijns ondanks' tog later die tug of dissipline 'n derde merkteken van die ware kerk verklaar het (Plomp 1969:126).

Sterk beïnvloed deur Bucer, maar ietwat anders as Luther en Zwingli, het Calvyn sorgvuldig aandag gegee aan die uiterlike organisasie, struktuur of orde van die kerk (Botha 1993:6; Van't Spijker 1994:35-37). Dit het hy gedoen omdat hy die sigbare kerk gesien het as van die grootste betekenis vir die bemiddeling van die verborge werk van die Heilige Gees (Van't Spijker 1988:98). As draer van die ware evangelie moet die kerk, om die taak reg te kan doen, ook 'n regte organisasie of orde hê wat Skriftuurlik gefundeer is (Pont 1981:3). Daarom durf die kerklike orde nooit verwaarloos word nie. Die verbondsvolk van God, in die kerk saamgebring, moet op 'n ordelike wyse in gehoorsaamheid aan die Skrif, aan God se Woord, leef.

Terwyl hy duidelik laat blyk dat die orde ' $n$ middel tot 'n doel is en nie doel op sigself nie, beklemtoon hy terselfdertyd die geweldige noodsaaklikheid daarvan dat dit nie maar pragmaties benader kan word nie.

Sy uitspraak in die Institusie is wel duidelik (Calvyn 1991:1522):

Soos die saligmakende leer van Christus die kerk se siel is, so is dissipline die kerk se senuwees waardeur die ledemate van die liggaam elkeen op sy plek onderling met mekaar in samehang is. Dissipline is dus as ' $t$ ware 'n toom waardeur diegene wat teen Christus se leer woed, teruggehou en getem kan word. Of dit is soos 'n prikkel om diegene aan te por wat te min gewillig is. Soms is dit selfs soos 'n vader se plak om diegene wat ernstiger afgedwaal het, met sagmoedigheid en vriendelikheid van Christus se Gees te tug.

(Calvyn 1991:1522)

Die ordereëls moet Skriftuurlik gefundeerd wees en daarom sê Calvyn (1991:1497): 'moet ek hier getuig dat ek uiteindelik slegs daardie menslike instellings goedkeur wat op sowel God se gesag gegrond as aan die Skrif ontleen is en wat daarom Goddelik is'. 
Dit beteken nie dat Calvyn bedoel dat elke kerklike ordereël op 'n presies ooreenkomende teks uit die Skrif gefundeer moet wees nie. Sy vereiste was wel dat die Bybelse grondgedagte tot sy reg moes kom. Coertzen (1991:24) toon aan dat Calvyn nie die Skrif op fundamentalistiese of biblisistiese wyse gebruik nie, maar dat hy wel die ius Divinum of die dinamiese orde wat in die kerk moes geld, gesoek het. Juis daarom het hy ook nie 'n onveranderlike kerkregeringsisteem uit die Skrif afgelees, of probeer aflees nie. Inteendeel, hy het dit uitdruklik gestel dat die Skrif geen volledige en pasklaar orde vir alle tye, omstandighede en plekke gee nie. In die Institusie stel hy:

Omdat dit egter nie sy wil was om in die uiterlike dissipline en seremonies uitdruklik voor te skryf wat ons moet volg nie, omdat Hy voorsien het dat dit van die tydsgewrig afhang en Hy geoordeel het dat een vorm daarvan nie by alle tye pas nie ... Ten slotte, omdat Hy niks uitdruklik hieroor geleer het nie, en omdat dit nie vir ons saligheid noodsaaklik is nie, en dit ooreenkomstig die gewoontes van elke volk en tyd verskillend aangepas moet word, sal dit paslik wees om enersyds gebruiklike instellings te verander en te herroep en andersyds nuwes in te stel na gelang die voordeel van die kerk dit vereis.

(Calvyn 1991:1497)

Dit beteken dat daar nie ' $n$ absoluut eenvormige en vaste patroon vir ' $n$ kerkorde wat uit Calvyn se kerkbegrip voortvloei, hoef te wees nie. 'n Vaste en Skriftuurlik gefundeerde kerklike orde verwag hy wel, maar nie 'n gekanoniseerde patroon van kerkorde nie. Hy laat groot vryheid toe soos dit uit sy kommentaar op 1 Korintiërs 11:2 blyk (Pont 1986:541): 'Want ons weet dat elke kerk die vryheid het om vir homself ' $n$ kerklike orde, wat vir hom ter sake en bruikbaar is, op te stel, want ons weet dat die Here nie iets bepaalds voorgeskryf het nie'.

Uit sy kommentaar op 1 Korintiërs 14:40 ('Alles moet egter gepas en ordelik geskied') blyk hierdie beskouing van Calvyn ook duidelik (Botha 1993:10). Hy stel dat die Here ten opsigte van uiterlike seremonies en gebruike aan die gelowiges vryheid van keuse gelaat het, sodat hulle nie sou kan dink dat die diens aan God totaal in die uiterlike seremonies en gebruike opgesluit lê nie. Maar dan stel hy onmiddellik daarby dat die Here hierdie vryheid van keuse tog getemper het, omdat daar oor sulke sake vanuit die Woord van God geoordeel moes word wat reg is. Dit moes reëls wees wat op die Woord van God gebou was om dissipline en orde in die kerk te handhaaf. Wat meer is, die ordereëlings wat afgelei is uit en gebou is op die Woord, kan nie maar net 
as menslike insettinge gesien word nie, maar in soverre hulle in die algemene gebod van gepas en ordelik gegrond is, het hulle soveel gesag asof hulle uit die mond van Christus self kom. Gehoorsaamheid daaraan is dan vanselfsprekend.

Plomp (1969:128) wys daarop dat dit een van die merkwaardige 'spelingen van de geschiedenis' is dat die dissipline by die gereformeerdes 'n nota ecclesiae geword het, terwyl Calvyn dit nie uitdruklik geleer het nie. Daarteenoor het Luther wel die dissipline as merkteken aanvaar terwyl die Lutherse konfessies dit afwys. Plomp is van mening dat as verklaring vir hierdie merkwaardigheid die feit in berekening gebring moet word dat Calvyn 'n baie subtiele onderskeid gemaak het tussen kerk en welgeordende kerk. Nie van eersgenoemde nie, maar wel van laasgenoemde, is die tug 'n merkteken (Plomp 1969:127). Op die wyse, so stel Plomp, het Calvyn 'n tussenposisie - 'men zou haast zeggen balanceerde hij - tussen die libertyne wat van die kerklike tug niks wou weet nie, en die Wederdopers wat gemeen het dat die kerk met die tug gestaan of geval het. Polman (s a:III 331) stel dit bietjie anders deur daarop te wys dat Calvyn die tug noodsaaklik geag het vir die welwese (bene esse) maar nie vir die wese (esse) van die kerk nie (vgl Pont 1986:543). Dit bly egter ook 'n feit dat Calvyn by een geleentheid wel in sy Institusie die dissipline in konteks met prediking en sakramente noem (Calvyn 1991:1365).

Om 'n bietjie meer volledig te wees, moet daar kortliks vir 'n oomblik nog teruggekeer word na Calvyn se metafoor dat die kerk liggaam van Christus is. Vir hom bestaan daar 'n noue verband tussen die priesterlike werk van Christus en die regverdiging van die mens; dit is tussen die vergewing van sonde wat bewerk is deur Christus se offerdood en die toe-eiening daarvan deur die geloof. Om geregverdig te wees veronderstel ook om in die liggaam van Christus, waarvan $\mathrm{Hy}$ die Hoof is, te wees. As Hoof verseker Jesus Christus nie alleen die stabiliteit, eenheid en kontinuïteit van die kerk nie, maar bepaal Hy ook die karakter van die liggaam (Milner 1970:181). Die dinamiese element word vir die liggaam voorsien deur die Heilige Gees. Wat Calvyn in die oog het met hierdie metafoor is dan die regverdiging; die vergewing van sonde. As liggaam van Christus is die kerk die gemeenskap van mense wie se sonde deur die geregtigheid van Christus vergewe is en wat nou in die krag van daardie geregtigheid kan lewe deur die opname in Hom (Milner 1970:188). Dit beteken nie dat die kerk nou sondeloos geword het nie. Ook hier geld die waarheid: simul iustus ac peccator.

Die denke van Calvyn oor kerkbegrip en kerkorde sou kortliks soos volg saamgevat kan word:

* Die kerk is 'n lewende dinamiese organisme, deur God geskape om orde in die skepping te herstel en tot God se eer te leef;

* dit is 'n geloofsgemeenskap wat in 'n verbondsverhouding tot God staan; 
* die grondbeginsel is dat Jesus Christus Heer en Hoof is, dit wil sê die kerk het 'n Christologiese hart en middelpunt;

* om te kan ontstaan en te kan voortbestaan het die kerk 'n organisatoriese, strukturele of institutêre kant waar die regte prediking en hoor van die Woord en die korrekte bediening en ontvang van die sakramente kan plaasvind;

* die Heilige Gees is die dinamiese krag waardeur Jesus Christus self die kerk onmiddellik deur die Woord en middellik deur die ampte regeer en versorg;

* die erediens vorm die hartklop van die kerk en daar word die orde van die kerk en die sin en die doel van die kerk, naamlik diens aan God tot eer van God, ook duidelik;

* daar bestaan ' $n$ onderskeiding, maar nie 'n skeiding nie tussen die sigbare en onsigbare kerk - die regte prediking en hoor en die korrekte bediening en ontvang van die sakramente vorm die merktekens wat met die wese van die kerk te make het;

* hoewel Calvyn dit nooit eksplisiet so gestel het nie, dring die regte hoor van die prediking en die korrekte ontvang van die sakramente as logiese afleiding die handhawing van die dissipline of tug as 'n saak, wat te make het met die welwese van die kerk, na vore;

* Calvyn was wel baie beslis dat die kerk 'n behoorlik Bybelsgefundeerde orde moes hê waarin tot uitdrukking sou kom dat Jesus Christus as Heer en Hoof alleen die kerk regeer, onmiddelik en middelik, en wat die kerk as volk van God in gehoorsame diens aan God kan lei; en

* die kerk verskyn in 'n volkskerklike gestalte onder die verskillende volke.

\section{DIE ORDONNANCES ECCLÉSIASTIQUE VAN GENÈVE 1541 (1561)}

In die Ordonnances wat in 1541 deur Calvyn ontwerp is en in 1561 geringe wysigings ondergaan het, het Calvyn vanuit sy kerkbegrip 'n kerkorde vir die kerk in Genève opgestel. Hoewel die kerkorde basies 'n skepping van Calvyn was, het die owerheid tog ook vereistes gestel en insette daaroor gelewer. Dit was wel in lyn met Calvyn se denke dat die kerk en die owerheid moes saam staan:

Die kerk moes die riglyne trek vir die godsdienstige en maatskaplike lewe van die volk, wat kragtens die doop, ook volk van die verbond is. Die owerheid moes die riglyne van die kerk volg en met die owerheidsgesag en die swaardmag die ware diens van God bevorder en beskerm.

(Pont 1981:21)

Tog het die owerheid te Genève meer gesag en invloed in die kerk gekry as wat Calvyn bedoel het (Pont 1981:21-22). 
Aan die ander kant is dit ook waar dat die Ordonnances Ecclesiastique sekerlik die belangrikste kerkorde van die sestiende eeu was waarin die beginsels van die presbiteriaal-sinodale orde saamgevat is en wat invloed uitgeoefen het op al die Calvinistiese kerke se kerkordes.

\section{KERKBEGRIP EN KERKORDE IN DIE CALVINISTIESE KERKE}

Die kerkbegrip van Calvyn en die kerkorde wat hy daarop gebou het, het wye navolging gevind en groot invloed geoefen oral waar die Calvinistiese hervorming deurgebreek het.

So het Calvyn direkte invloed gehad op die Confession de foi (Confessio Gallicana) en die Discipline Ecclesiastique wat op die Sinode van Parys vanaf 25 tot 29 Mei 1559 vir die Franse Hervormde Kerk vasgestel is (Bakhuizen van den Brink \& Lindeboom 1946:150). Die Confessio Gallicana was op sy beurt na vorm en inhoud die moederkonfessie van die Confessio Belgica of Nederlandse Geloofsbelydenis wat in 1561 deur Guido de Brés opgestel is (Bakhuizen van der Brink \& Lindeboom 1946:151). Die Discipline Ecclesiastique het saam met die Geneefse Ordonnances Ecclesiastiques beslissende invloed gehad op die Waalse kerkordenende reëlings en ook op die latere Nederlandse kerkordenende reëlings vanaf Wezel 1568 tot Dordt 1618-1619 (Pont 1981:71). Calvyn se denke oor die kerk en die orde van die kerk het, behalwe vir die Franse en Nederlandse Hervormde Kerke, ook in ander lande bepalende invloed uitgeoefen, soos onder andere in Skotland, sekere dele van Duitsland en Hongarye (McNeill 1967:237-350). Dit het nie tot gevolg gehad dat daar oral presies dieselfde kerkorde ontstaan het nie. Calvyn se eie standpunt dat die kerk vir elke tyd, omstandigheid en volk ' $n$ eie kerkorde benodig, het so 'n eenvormige en eendersluidende kerkorde onmoontlik gemaak.

Vir hierdie studie is dit van belang om vir 'n oomblik na die Nederlandse Geloofsbelydenis en die verskillende Nederlandse kerkordes te kyk. Hoewel Polman (s a:III 270) aantoon dat De Brés op voortreflike wyse die kerngedagtes van die verskillende Reformatore oor die kerk in sy geloofsbelydenis saamgevat het, was Calvyn se invloed en denke tog die vernaamste en bepalende, en volgens Koopmans (1949:10) het De Brés die belydenis selfs vir beoordeling aan Calvyn voorgelê.

In Artikels 27 tot 32 word inderdaad die hoofgedagtes van Calvyn oor die kerk teruggevind. In dié artikels word nie net die breë lyne vir die verstaan van die begrip kerk aangegee nie, maar ook dié ten opsigte van die orde van die kerk (Pont 1981:10). Vandaar vind dit neerslag in die eerste konseporde van die Convent van Wezel van 1568 en daarna in al die ordes tot by die groot sinode van Dordt 1618-1619 wat 'n kerkorde opstel waarvan gesê word dat dit 'in baie opsigte beskou kan word as die klassieke uitdrukking van die presbiteriaal-sinodale sisteem van kerkregering, soos dit in Nederland in die sestiende en sewentiende eeu ontwikkel. het ...' (Pont 1981:171). 
Trouens in die kerkordenende werk vanaf Wezel tot by Dordt het dit daarom gegaan om dit wat in Artikels 27 tot 32 en selfs tot 35 bely word, uit te werk tot praktiese reëlings (Pont 1981:71).

In een opsig het die Nederlandse Geloofsbelydenis bietjie verder gegaan as Calvyn self, maar daarmee aangesluit by sommige van Calvyn se geesgenote en leerlinge en dit is om ook die tug of dissipline as merkteken van die ware kerk te bely (Artikel 29). Hoewel daar reeds daarna verwys is as 'n merkwaardigheid, is dit tog aan die ander kant in 'n sekere sin ' $n$ vanselfsprekendheid 'omdat Woordverkondiging en sakramentsbediening uiteraard alleen 'binne 'n bepaalde kerklike ordening plaasvind' (Pont 1981:10).

Hierdie ontwikkeling het ongelukkig ook negatiewe gevolge ingehou. Dit was veral te danke aan diegene wat van die standpunt uitgegaan het dat die kerkordelike struktuur, in elke besonderheid, 'n Skriftuurlike gegewene was. Pont stel:

Die gevolg is dat daar aan die ordereëls 'n oormatige gewig gegee word teenoor die sentrale, Christologiese moment van die kerkwees wat altyd deur Calvyn benadruk is. Daardeur het die opvatting reeds in die laatsestiende en sewentiende eeu posgevat dat die kerk 'n struktuur is en dat die strukturele die kerkwees van die kerk bepaal.

(Pont 1981:542)

Anders as Calvyn wat die dissipline betrek het op die Christologiese hart van die kerk, die prediking van die Woord, het die Anabaptiste, die Engelse separatiste, die Puriteine en die Nederlandse Nadere Reformasie dit op die grense van die kerk toegepas. Dit het 'n belangrike rol by die afskeidings van die Nederlandse Hervormde Kerk gedurende die negentiende eeu gespeel (Pont 1986:544-545). Wat in wese gebeur het, was dat 'die struktuur belangriker geword (het) as die lewende liggaam, die organies-dinamiese volk van God wat ontstaan en voortbestaan deur die regte prediking van die evangelie van Jesus Christus' (Pont 1986:544).

Die afskeidingsbewegings in Nederland het aan die een kant nie genoegsaam rekening gehou met die feit dat, hoewel die dissipline eksplisiet in die Nederlandse Geloofsbelydenis Artikel 29 genoem is as merkteken, dit daar die derde plek in 'n besliste rangorde ingeneem het nie. Aan die ander kant is die afskeidings gestimuleer

deur die feit dat die Nederlandse volkskerk sy leerstellige basis, die verbond, onder druk van die humanisties-moralistiese liberale teologieë verwaarloos het en homself as 'n vrywillige vereniging, gekonstitueer volgens die heersende verligte verenigingsreg in 'n demokratiese staat, omskryf het.

(Pont 1986:544) 
Wat dus basies in die kerklike gebeure in die negentiende eeu met die afskeidings van 1834 en 1886 in Nederland na vore gekom het, was tweërlei. Eerstens kom die vryekerk-gedagte (sien Pont 1987:25-46) na vore waarin die struktuur en dissipline - me1 die oog op suiwerheid van leer en lewe - van 'n vrye kerk langs die landskerk met presies dieselfde belydenisskrifte as geregverdig beskou is, en waarin die Dordtse kerkordelike reëlings van 1618-1619 gekanoniseer is as die enigste kerkorde wat steeds in die negentiende eeu die kerkbegrip van die belydenisskrifte gedra het.

Tweedens kom die landskerk of volkskerk na vore met 'n kerkordelike bestel wat hoegenaamd nie gebou was op die kerkbegrip soos wat dit uit Skrif en belydenisskrif afgelei kan word nie. Dit was die gevolg van die sogenaamde Algemeen Reglement van 1816 wat van owerheidsweë op die Nederlandse Hervormde kerk gelê is. Hierdie $\mathrm{Al}$ gemeen Reglement het nie uit die kerk self na vore gekom as 'n kerkorde wat die gevolg was van die kerk se eie teologiese refleksie oor 'n eie kerkbegrip wat in Skrif en belydenisskrif gevind is nie. Wat in 1816 gebeur het, was dat die struktuur van die kerk in wese losgemaak is van die geloof en leer van die kerk. Die verbintenis tussen Skrif, belydenis en kerkorde is verbreek en die kerkorde was hoegenaamd nie meer 'n weergawe van die kerkbegrip van die kerk nie (Pont 1991:28; Van Wyk 1989:134151). Verder is die vorm waarin die kerkordelike reëls gegiet is, ook totaal verander.

In die negentiende eeu was dit feitlik net Hermann Friedrich Kohlbrugge (Rasker 1974:100-112) en Philippus Jacobus Hoedemaker (Scheers 1939:184-232) wat hierdie saak skerp raakgesien het en daarteen gereageer het. Dit was by uitstek Hoedemaker wat hom volhardend bly beywer het vir die gedagte van die verbondsmatige volkskerk, soos hy dit by Calvyn teruggevind het. Daarteenoor was Kuyper, wat die Doleansiebeweging en afskeiding van 1816 gelei het, onverbiddelik in sy ywer om die volkskerk te vernietig en die vrye kerk te vestig. Ook hy het gemeen om by Calvyn aan te sluit. Berkhof stel daarom:

Calvijns kerkstaatideaal is bij Kuyper en Hoedemaker in twee teenstrijdige beginselen gesplitst. Calvijn wilde de heilige volkskerk. Kuyper gaf ter wille der heiligheid het volk prijs. Hoedemaker hield allereerst het volk vast, om dan tot de heiligheid te komen.

(Berkhof 1950:297)

Dit sou 'n stryd van meer as honderd jaar kos om binne die Nederduitsch Hervormde Kerk weer by 'n kerkorde uit te kom wat in die verlengde gelê het van die reformatoriese en spesifiek Calvinistiese kerkbegrip en kerkorde soos dit in die Nederlandse Geloofsbelydenis (27-32) verwoord is (Van Wyk 1989:208-230; Rasker 1974:267276). Dit het eers gebeur met die aanvaarding van 'n nuwe kerkorde in die Nederlandse Hervormde kerk in 1950 (Van Wyk 1989:197). 
Dit is nietemin belangrik om daarop te let dat, ten spyte van die feit dat die afgeskeie kerke in Nederland verabsoluterend teruggegryp het na die Dordtse Kerkorde, dit tog nie op die lang duur kon verhinder dat afwykende leerstellige beskouinge in die Gereformeerde Kerke van Nederland sou indring nie. Terselfdertyd kon die afwykende kerkorde in die Nederlandse Kerk nie verhinder dat die kerk langs die weg van reorganisasie die kerkorde kon reformeer om weer in lyn te lê met die kerkbegrip van sy eie belydenisskrifte nie.

\section{DIE KERK EN KERKREGTELIKE ONTWIKKELING IN SUID-AFRIKA}

Vanaf die volksplanting en kerkplanting in 1652 deur Jan van Riebeeck is die kerk in Suid Afrika, en dan by name die Hollands-Afrikaanse kerke, nog tot 'n paar dekades gelede baie sterk vanuit Nederland beïnvloed. Gebeure op kerklike werf in Nederland is meermale in Suid-Afrika deur feitlik identiese gebeure gevolg. Die noue bande wat om ' $n$ verskeidenheid van redes tussen Nederland en Suid-Afrika bestaan het, het dit logies en feitlik vanselfsprekend gemaak. Ook op kerkordelike terrein kan hierdie patroon waargeneem word (sien Pont 1991:132-369; Vorster 1956; Kleynhans 1973).

Hoewel nie amptelik nie, het die Dordtse Kerkorde in praktyk tot in 1803 in die Kaapse kerk gefunksioneer (Pont 1991:140-143). Met die Bataafse bewind vanaf 1803 tot 1806 en Provisioneéle Kerken-Orde van J A de Mist van 1804 begin dieselfde verskuiwing as wat in Nederland voorgekom het, en word van die gedagtes van die Aufklärung en die Franse rewolusie ook aan die Kaap ingedra. Onder andere word die owerheid neutraal en die kerk word gesien as 'n blote vrywillige vereniging (Pont 1991:192). Die kerkbegrip wat na vore kom in hierdie Kerken-Orde, was nie naastenby meer die kerkbegrip van Calvyn en die belydenisskrifte nie.

Ook die eerste eie kerkordes van die kerk aan die Kaap, of soos dit genoem is Algemeen reglement voor het bestuur der Nederduitsche Hervormde Kerk, in Zuid Afri$k a$ van 1824 en van 1842/3, trek basies presies dieselfde lyne as die Algemeen Reglement van 1816 van Nederland en is ook basies presies in lyn met die verenigingsreg (Pont 1991:239-248, 267-269).

Ook met die vestiging van die Nederduitsch Hervormde Kerk in Transvaal is die voorbeeld van die Kaapse kerk ten opsigte van 'n eie kerkorde feitlik klakkeloos nagevolg (Botha [1962]:25-35; Pont [1962]:36-47). Die gevolg was dat vanaf die eerste amptelike Kerkwet van 1862 tot met die aanvaarding van 'n 'nuwe' Kerkwet in 1951, kerkordelike reëlings in die Nederduitsch Hervormde Kerk gegeld het wat hoegenaamd nie in lyn was met die kerkbegrip en presbiteriaal-sinodale kerkorde van Calvyn, soos wat dit onder andere neerslag gevind het in die Nederlandse Geloofsbelydenis (artikels 27-32), die Heidelbergse Kategismus (Sondag 21, Vraag en Antwoord 54) en die ver- 
skillende Nederlandse kerkordes voor 1816 nie. Inderdaad het die kerkordes of kerkwette soos dit genoem is, op ' $\mathrm{n}$ totaal vreemde kerkbegrip, soos dit uit die Aufklärung na vore gekom het, gerus en dit was inderdaad niks anders as verenigingsreg nie (Van Wyk 1989:353).

Met die aanvaarding van 'n 'nuwe' Kerkwet in 1951 het die Nederduitsch Hervormde Kerk sy tradisie voortgesit om die ontwikkeling in die Nederlandse Hervormde Kerk na te volg. In werklikheid was die Kerkwet van 1951 niks meer nie as 'n aanpassing van die Nederlandse Hervormde Kerk se Kerkorde van 1950 (Van Wyk 1989: 231-235). Die Kerkvyet van 1951 was in elk geval 'n groot verandering en verbetering ten opsigte van die kerkwette wat voor die datum van krag was. Die presbiteriaalsinodale tradisie het in hierdie Kerkwet die oorheersende geword. Ongelukkig het daar nog oorblyfsels van die verenigingsregstradisie steeds neerslag gevind in die Kerkwet van 1951 (Pont 1981:4) wat die presbiteriaal-sinodale sisteem tog weer deurkruis. Dit het 'n sekulariserende en demokratiserende tendens in die kerkordelike struktuur van die Nederduitsch Hervormde Kerk ingedra wat nogal diep wortel geskiet het. Dit het daartoe bygedra dat die nadelige invloede van die verenigingsregdenke, wat blykbaar ook makliker begryp word as die reformatories-kerkregtelike denke, steeds latent in die kerk teenwoordig is (Van Wyk 1989:354).

Ten spyte van die 'goeie' wat die Kerkwet van 1951 ingehou het, het daar om begryplike redes gaandeweg twee groot besware al sterker na vore begin tree. Een was dat die Kerkwet nie uit die eie studie, besinning en gesprek wat die eie omstandighede kon verdiskonteer, voortgekom het nie (vgl Calvyn se gedagtes), maar dat dit al meer ervaar is as iets wat van buite af aan die kerk opgelê is (Pont [1983]:28). Terloops, dit is interessant om te meld dat die Nederlandse Kerkorde van 1950 ook die afgelope jare in Nederland self skerp gekritiseer word (Dingemans 1987:44-75). Die tweede beswaar is teen die oorblyfsels van die verenigingsreg waarin die statutêr-juridiese opvattings die Christokraties-pneumatiese oorwegings totaal oorskadu (Pont 1982a:12). Ten spyte van voortdurende aanpassings en verstellings oor die afgelope veertig jaar, het dit gaandeweg nodig geword dat drastieser optrede tog nodig is.

Dit sou nie korrek wees om uit voorgaande die afleiding te maak dat die Nederduitsch Hervormde Kerk as gevolg van die genoemde besware die wesenlike van kerkwees, in die sin soos dit in die Bybels-Reformatoriese teologie verstaan is, te kon handhaaf nie. Pont (1986:545) toon aan dat die konstituerende Christologiese middelpunt soos Calvyn dit geformuleer het, in die kerk en die kerklike lewe wel deeglik volle aandag gekry het. Die prediking het Christosentries gebly en die dissipline, ook leertug, is gehandhaaf. 
Nogtans is die besluit wat gelei het tot die herskrywing van die Kerkorde, volkome begryplik binne 'n kerk waar die beginsel ecclesia reformata semper reformanda verbo Dei est erken word.

\section{SAMEVATTING}

Daar kan geargumenteer word dat die werk van die kerk veel belangriker is as die struktuur van die kerk en dat 'n 'suiwer' kerkbegrip daarom ook veel belangriker is as 'n 'suiwer' kerkorde. Inderdaad kan daar uit die geskiedenis bewys word dat 'n suiwer kerkorde nie altyd 'n waarborg is dat die kerk sy primêre opdrag van Woordverkondiging suiwer uitvoer nie en ook dat 'n 'onsuiwer' kerkorde nie noodwendig suiwere Woordverkondiging in die weg hoef te staan nie.

Tog is dit van die grootste belang dat daar nie net oor kerkbegrip nie, maar ook oor ' $n$ kerkorde sorgvuldig nagedink sal word. Al is en bly die kerkbegrip die bepalende, is dit ook net so waar dat die kerkorde die totale lewe van die kerk, die liggaam van Christus, die volk van God, raak. Die heil, dit wil sê die vrede met God, die versoening, die redding en verlossing in en deur Jesus Christus, alles gawes van God, is by sowel kerkbegrip as kerkorde betrokke (Botha 1993:3-14). Inderdaad is die organisatoriese struktuur of kerkorde 'n middel tot 'n doel en nie die doel self nie (Pont 1981; 1986:534-546).

Maar dit beteken nie dat die orde net met die uiterlike te doen het en daarom onbelangrik is en alleen maar pragmaties benader kan word nie. As noukeurige nadenke oor die kerk nodig is, is noukeurige nadenke oor die orde as voortvloeisel daaruit, net so noodsaaklik.

Van Wyk gee twee omskrywings of definisies wat as vertrekpunte vir besinning oor kerkbegrip geneem kan word:

Die Kerkbegrip ... wat omskryf kan word as die knooppunt van kerklike denke, as die gesistematiseerde samevatting van wat oor die kerk, deur die Skrif en die belydenis gestel word. Die kerkbegrip stel dus hoe na die Skrif en belydenis geluister is.

(Van Wyk 1989:26)

Die kerkbegrip is die resultaat waartoe gekom word na grondige bestudering van die Skrif as norma normans en ootmoedige belydenis soos geformuleer in die belydenisskrifte as norma normata met betrekking tot die Skrif.

(Van Wyk 1989:28) 
Ten opsigte van 'n kerkorde gee Van Wyk (1989:207-208) die volgende kort omskrywing: "' $\mathrm{K}$ Kerkorde ... is die maatstaf deur Skrif en belydenis genormeer wat die werk van die kerk in die praktyk rigtinggewend wil begelei om diensbaar te wees aan die alleen-heerskappy van Jesus Christus'.

Al drie hierdie omskrywings van Van Wyk moet geplaas word binne die konteks van die presbiteriaal-sinodale kerkregeringsisteem. Saamgelees is dit uit hierdie omskrywings duidelik dat binne die presbiteriaal-sinodale konteks Skrif, belydenisskrif en kerkorde nie los van mekaar gesien kan word nie. Inteendeel, hulle lê in mekaar se verlengde en daar moet ' $n$ noue verband tussen hulle bestaan. Dit het ook geblyk uit die gedagtes oor kerkbegrip en kerkorde by Calvyn.

Dit beteken dat daar by die herskrywing van 'n kerkorde eers weer sorgvuldig nagedink sal moet word oor hoe die kerk verstaan word vanuit Skrif en belydenisskrif. Binne die Nederduitsch Hervormde Kerk sal die vraag daarom beantwoord moet word hoe daar tans oor die kerk gedink word. Wat minstens aanvaar sou kan word is dat die kerkbegrip wat in die belydenisskrifte, naamlik die Nederlandse Geloofsbelydenis en die Heidelbergse Kategismus na vore kom, steeds die hooflyne van die kerkbegrip binne die Nederduitsch Hervormde Kerk uitmaak. Of daar oor alle ander aspekte van die kerk, soos onder andere die gedagte van die volkskerk-model, totale eenstemmigheid in die Nederduitsch Hervormde Kerk heers, is nie heeltemaal duidelik nie.

As aanvaar kan word dat die kerkbegrip soos dit in die Nederlandse Geloofsbelydenis en die Heidelbergse Kategismus na vore kom, steeds aanvaar word, sal ook aanvaar kan word dat ' $n$ nuwe kerkorde minstens gebou sal word op wat daar oor die kerk bely word. Die uitgangspunt sal dan moet wees dat Jesus Christus die enigste Heer en Hoof van die kerk, sy kerk regeer, onmiddellik deur Gees en Woord en middellik deur die ampte of dienste.

Daarom sal die prediking van die Woord steeds die primêre plek moet inneem as die element wat die kerk konstitueer en die orde skep. Ondersteunend daartoe kom die bediening van die sakramente as die 'sigbare Woord'. In die kerkorde sal die erediens daarom ook as hartklop van die kerk ingeorden moet word. Om dit moontlik te maak sal erken moet word dat alle gesag in Jesus Christus alleen lê en daarom geld sy Woord, soos in die Skrif gevind, onder alle omstandighede en te alle tye as normatief. Dit sluit elke vorm van hiërargie uit (Pont 1982b:24). In die lig sal die ampte, die vergaderings van die ampte, die godsdiensoefeninge en die tug ook georden moet word.

\section{Literatuurverwysings}

Bakhuizen van den Brink, J N \& Lindeboom, J 1946. Handboek der kerkgeschiedenis, Tweede deel. s'Gravenhage: D A Daamans. 
Berkhof, H 1950. Geschiedenis der kerk. Nijkerk: Callenbach.

Botha, S J 1963. Die historiese agtergrond van die Kerkwet van 1862 van die Nederduitsch Hervormde Kerk in die ZAR. HTS 19, 25-35.

- 1993. Die heil, gehoorsaamheid, struktuur en kerkreg. Pretoria: Universiteit van Pretoria. (Nuwe reeks $\mathrm{nr} 285$.)

Calvinus, J 1549. Commentaries on the epistle to the Hebrews, translated by J Owen. Grand Rapids: Eerdmans.

- 1991. Instituto Christianae Religionis, vertaal deur H W Simpson. Potchefstroom: CJBF.

Coertzen, P 1991. Gepas en ordelik: 'n Teologiese verantwoording van die orde vir en in die kerk. Pretoria: RGN uitgewers.

Dankbaar, W F 1957. Calvijn: Zijn weg en werk. Nijkerk: Callenbach.

Dingemans, G D J 1987. Een huis om in te wonen: Schetsen en boustenen voor een kerk en een kerkorde van de toekomst. s'Gravenhage: Uitgevery Boekencentrum BV.

Haitjema, Th L 1951. Nederlands Hervormd kerkrecht. Nijkerk: Callenbach.

Kleynhans, E P J 1973. Die kerkregtelike ontwikkeling van die Nederduitse Gereformeerde Kerk in Suid-Afrika: 1795-1962. DTh-proefskrif, Universiteit van Stellenbosch.

Koopmans, J 1949. Die Nederlandse Geloofsbelijdenis. Amsterdam: Uitgeversmaatshappij Holland.

Langman, H J 1950. Kuyper en de Volkskerk: Een dogmatisch-ecclesiologisch studie. Kampen: J H Kok.

McNeill, John T 1967. The history and character of Calvinism. New York: Oxford University Press.

Milner, B C 1970. Calvin's doctrine of the Church. Leiden: Brill.

Nederduitsch Hervormde Kerk van Afrika. Algemene Kerkvergadering 1989. Notule van die Algemene Kerkvergadering 1989. Argief van die Nederduitsch Hervormde Kerk, Pretoria.

Nederduitsch Hervormde Kerk van Afrika. Algemene Kerkvergadering 1992. Notule van die Algemene Kerkvergadering 1992. Argief van die Nederduitsch Hervormde Kerk, Pretoria.

Plomp, J 1969. De Kerkelijke tucht bij Calvijn. Kampen: J H Kok.

Pont, A D 1963. Oor die Kerkwet van 1862. HTS 19, 36-46.

- [1977]. Skrif en kerkorde - enkele opmerkings. HTS 33, 77-90.

- 1981. Die historiese agtergronde van ons kerklike reg, Deel 1. Pretoria: HAUM.

- [1982]a. Kerk en struktuur. HTS 38, 1-22. 
Pont, A D [1982]b. Wat hoort tuis in 'n kerkwet of kerkorce in die lig van die Skrif en die belydenis. HTS 38, 23-35.

- 1986. Calvijn en die kerklike orde. HTS 42, 534-546.

- 1987. Die vrye kerk: Enkele opmerkings oor die herkoms en inhoud van die opvatting. HTS 43, 25-46.

- 1991. Die historiese agtergronde van ons kerklike reg, Deel 2. Pretoria: Kital.

Rasker, A J 1974. De Nederlandse Hervormde Kerk vanaf 1795. Kampen: J H Kok.

Scheers, G Ph 1939. Philippus Jacobus Hoedemaker. Wageningen: H Veenman en zonen.

Smit, C J 1984. God se orde vir sy kerk - 'n beskouing oor kerkorde. Pretoria: NGKB.

Smit, C J 1985. Kerkreg en kerkorde - in die lig van God se reg en orde vir sy kerk. ThD-proefskrif, Potchefstroomse Universiteit vir Christelike Hoër Onderwys.

Van Niftrik, G C 1953. Kleine Dogmatiek. Nijkerk: Callenbach.

Van Ruler, A A 1967. De betekenis van het institutaire (in de kerk). Kerk en Theologie 18, 309-335.

Van't Spijker, W 1988. De opvattingen van de Reformatoren, in Van't Spijker, W et al, Inleiding tot de studie van het Kerkrecht. Kampen: J H Kok.

- 1994. Bucer's influence on Calvin: Church and community, in Wright, D F (ed), Martin Bucer - reforming church and community. Cambridge: University Press.

Van't Spijker, W \& Van Drimmelen, L C (reds) 1988. Inleiding tot de studie van het Kerkrecht. Kampen: J H Kok.

Van Wyk, B J 1989. Die presbiteriaal-sinodale kerkbegrip met besondere verwysing na die Kerkwet van die Nederduitsch Hervormde Kerk van Afrika. DD-proefskrif, Universiteit van Pretoria.

Vorster, J D 1956. Die kerkregtelike ontwikkeling van die Kaapse kerk onder die Kompanjie. Potchefstroom: Pro Rege.

Wright, D F (ed) 1994. Martin Bucer - reforming church and community. Cambridge: University Press. 